\title{
Marker-assisted selection for transfer of submergence tolerance, bacterial blight resistance and yield enhancement in the rice backcross derivatives
}

\author{
Shibani Mohapatra ${ }^{1}$, Akshaya Kumar Bastia ${ }^{2}$, Alok Kumar Panda ${ }^{3}$ and Sharat Kumar Pradhan*1 \\ ${ }^{1}$ ICAR- National Rice Research Institute, Cuttack, Odisha, India \\ ${ }^{2}$ North Orissa University, Baripada, Odisha, India \\ ${ }^{3}$ School of Applied Sciences, KIIT Deemed to be University, Bhubaneswar, Odisha, India
}

*Corresponding author: pradhancrri@gmail.com

Abstract

Achieving the demand and supply of rice for the increasing global population will be a challenging task beyond 2040. Therefore, the yield potential of popular rice varieties needs to be increased. The production from lowland rice can be enhanced by managing the major biotic and abiotic stresses faced in the ecology. In this work, we have developed the pipelines for gene stacking of submergence tolerance, bacterial blight resistance and yield component QTLs in the popular rice variety 'Swarna' by marker-assisted backcross breeding approach. Genotyping results of $796 \mathrm{BC}_{1} \mathrm{~F}_{1}$ backcross derived lines showed the presence of GW2, OsSPL14, SCM2 yield component QTLs, Sub1A for submergence tolerance and bacterial blight resistance genes $x a 5$ and $X a 21$ in the progenies. The four stacked QTLs and two resistance genes were observed in six backcrosses derived progenies only. These progenies will be used in the next generation for further selection and evaluation for enhancing submergence tolerance, yield potential and bacterial blight resistance in Swarna rice variety background.

Keywords: Yield QTL, submergence tolerance, bacterial blight resistance, wealthy farmers panicle, strong culm, backcross breeding. Abbreviations: QTL_Quantitative trait locus, BBB_acterial blight, MAS_Marker-assisted selection, CTAB_Cetyltrimethylammonium bromide, EDTA_Ethylenediaminetetra acetic acid, TBE_Tris Borate EDTA.

Introduction

Rice is the principal food for the majority of the world's population and is grown under a diverse range of agro-climatic conditions. Rice cultivation is associated with major biotic and abiotic stresses that minimize the productivity of rice from lowland ecosystems. Among abiotic stresses, submergence and water logging are the major constraints for low productivity in the ecology. Submergence due to flash flood is a major problem for rice production in the rainfed lowland rice ecosystem of eastern India, which spreads over around 16 Mha in the country (Pradhan et al., 2016). Bacterial blight (BB) is a common, wide spread critical disease faced by rice plants (Oryza sativa L.). It is caused by Xanthomonas oryzaepv. oryzae. $\mathrm{BB}$ is one of the oldest recorded rice disease and it interrupts production in all rice ecosystems.

Our country needs additional rice production of around 2 million tons annually and a total of 135 to 140 million tons by 2030 to continue to remain self-sufficient. This production increase needs to be obtained from less land, less water, less labor and fewer chemicals under the constant threat of new emerging pathogens and pests and possible challenging effects of climate change (Khush, 2005). The global rice production needs to be enhanced by $70 \%$ by 2050 to meet the demand of the growing population (FAO, 2009; NRRI, 2013). The current rice production of India is 110 million tons per annum that need to be enhanced to 150 million tons in the coming 30 years (NRRI, 2013). To achieve this targeted yield level, rice varieties with a yield advantage of about $20 \%$ over widely grown varieties must be developed.

The traits influencing yield and tolerance to stresses have been selected by human since time immemorial. Those selections were based on yield component traits. However, many yield QTLs have been identified and also few are cloned during the last few years. Attempts are to be made for the accumulation of these QTLs in a single background for their effects in a positive or negative direction. The important yield component traits such as grain number (Gn1a, Ghd7, DEP1 and WFP), grain weight (GS3 and GW2), grain size (GS3 and GW5), grain filling (GIF1) and panicle number (DEP1 and WFP) may be utilized for enhancing yield potential. Tightly linked and functional markers of these yield related cloned genes may be useful for markerassisted pyramiding of yield component QTLs. Ashikari et al. (2005) reported the gene stacking of grain number and dwarfing gene combination for enhancement of yield. Swarna is the most popular rice variety in eastern India but the variety is sensitive to submergence and susceptible to 
bacterial leaf blight disease. There is a need for submergence tolerant and bacterial blight resistant version of Swarna variety for the eastern region of the country. Also, the yield potential of this variety needs to be enhanced further.

The objective of this study is to stack resistance genes/QTLs in Swarna variety for submergence tolerance, bacterial leaf blight resistance and more yield potential into the popular rice variety through marker-assisted backcross breeding approach.

\section{Results and discussion}

\section{Validation of submergence tolerance, bacterial leaf blight resistance and yield component QTLs in the parental lines}

The PCR amplification pattern using the genomic DNA of Swarna-Sub1, Swarna MAS, Swarna- Havataki derived lines and susceptible variety Swarna with molecular markers of Sub1A, $x a 5, x a 13$ and $x a 21$ were performed and depicted in the Fig. 1. All the specific lines showed the presence of resistance specific bands indicating the presence of resistance genes Sub1A, xa5, $x a 13$, and $X a 21$, respectively. All donor lines showed the presence of resistance specific bands of $1000 \mathrm{bp}, 530 \mathrm{bp}$ and $490 \mathrm{bp}, 440 \mathrm{bp}$ and $410 \mathrm{bp}$ indicating the presence of BB resistance genes, $x a 5, x a 13, X a 21$, respectively. The genotype Swarna MAS showed the presence and in the case of SwarnaSub1, Swarna-Havataki derived lines and Swarna there is no band against BB markers. Like that, in Swarna-Sub1 variety, the presence of Sub1A marker was detected and that gene was not in other donor lines viz., Swarna MAS, Swarna-Havataki and Swarna, indicating the absence of these resistance genes.

\section{Generation of $F_{1}, F_{1}^{\prime}$ and $B C_{1} F_{1}$ seeds}

The first hybridization was done between Swarna-Sub1 and Swarna MAS and $205 F_{1}$ seeds were produced. Next season, the true $F_{1}$ plant was hybridized with the yield QTLs containing Swarna-Havataki derivative lines and $170 \mathrm{~F}_{1}{ }^{\prime}$ seeds were obtained. True hybridity was again checked using OsSPL14 gene specific marker and true $F_{1}{ }^{\prime}$ plant was hybridized with recipient parent Swarna and $850 B C_{1} F_{1}$ seeds were produced.

\section{Marker- assisted selection for submergence tolerance, $B B$ resistance and higher yield potential in $B C_{1} F_{1}$ generation}

The amplification of the genomic DNA of seven-ninety-six genotypes was performed using gene-based direct markers for strong culm, wealthy farmers' panicle, grain width and submergence tolerance (Table1). Amplification of SCM2 indicates the presence of strong culm in the amplified genotypes. It is generally considered amplification of GW2 gene corresponds to the presence of low grain width and higher grain weight (Song et al. 2007). The expression of OsSPL14 QTL signifies the trait, wealthy farmer's panicle, which elucidates about the overall plant architecture. This study also states that OSSPL14 gene is also responsible for shoot branching during the vegetative stage. Submergence tolerance of rice a variety is mainly observed by the expression of Sub1A QTL. Direct marker Sub1A203 for submergence tolerance is better than Sub1BC2, this marker is an intergenic marker and is adjacent to Sub1A. Earlier reports suggest that the marker combinations of Sub1A203 + Sub1BC2 could group the genotypes in a more efficient and systematic manner.

There are 42 bacterial blight resistance genes that have been identified from diverse sources (Pradhan et al., 2018). Many of these genes have been tagged by closely linked molecular markers (Gu et al., 2008; Rao et al., 2002; Sonti, 1998; Yoshimura et al., 1995). Among them, 11 are recessive in nature. $x a 5$ is one of those recessive genes which gives tolerance to bacterial blight along with the dominant gene Xa21. In this study, we have taken the above three characteristics and accordingly, we have used molecular markers to screen the presence of submergence tolerance, yield potential and bacterial blight resistance in a number of progenies. All progenies from $\mathrm{BC}_{1} \mathrm{~F}_{1}-\mathrm{SM}-1$ to $\mathrm{BC}_{1} \mathrm{~F}_{1}-\mathrm{SM}-796$ were screened and they exhibited specific bands for various genes as stated below (Fig. 3; Fig. 4). Among these plants, some will be selected for further hybridization for getting the most desirable plant. Grain width and weight may play an important role in increasing grain yield in rice. High grain width increases yield while low grain width increases grain quality of rice. Here, in this present experiment, GW2 is a functional gene that indicates enhancement in grain width in rice (Song et al., 2007). In this work, out of 796 progenies, 238 progenies harbored GW2 gene. A strong culm is an important trait of rice plant which provides non-lodging character to the plant. Any plant devoid of strong culm may not be able to bear a heavy panicle load which ultimately may lodge leading to high yield loss. The results from our experiment indicated that two hundred eighty-four genotypes out of seven hundred ninetysix were positive for SCM2 QTL. Hence, our selection method for strong culm may be effective effective due to the presence of SCM2 QTL that imparts sturdy culm to the plant. Previously, Ookawa et al. reported that the presence of SCM2 provided a strong culm to the rice genotype (Ookawa et al., 2010). Wealthy Farmers Panicle controlled by OsSPL14 is a useful QTL for panicle trait for increasing yield potential. The direct marker OsSPL14 was employed in the genotyping of the backcross progenies that showed the presence of OSSPL14 in 274 genotypes out of atotal of 796 screened genotypes (Fig. 3; Fig. 4). For submergence tolerance, the markers mainly Sub1A203 and Sub1BC2 were used in this study to screen the 796progenies. The combination of Sub1A203 and BC2Sub1 showed a better resolution as compared to all other combinations. Out of 796 plants, we found Sub1A203 in 163 plants and BC2Sub1 in 365 plants. This combination is considered to be a good combination to screen the submergence tolerance in rice (Pradhan et al., 2016). In this study, we observed the amplification of 143plants for both the submergence tolerance markers combination. Hence, 143 plants may contain Sub1 QTL (Fig. 3; Fig. 4). All the desired genes that have been considered in the present work have been cloned and characterized. Xa21 is a dominant resistant gene that encodes the receptor kinase containing NBS-LRR domains (Song et al., 1995) while $x a 5$ is a recessive resistance gene and encodes a variant form of transcription factor IIA (Cllalyer and McCouch, 2004). In this present work, we have

Table 1. Molecular markers used for tracking of submergence tolerance, yield componentQTLs and bacterial leaf Blight resistance gene. 


\begin{tabular}{|c|c|c|c|c|}
\hline Sl. No & Characters & Markers & Primer Sequence & Reference \\
\hline \multirow[t]{2}{*}{1} & Grain width & $G W 2(\mathrm{~F})$ & $5^{\prime}$ CCAATAAAGATGTCCATTCTGTTA 3' & Song et al., 2007 \\
\hline & & GW2 (R) & 5'GCTCTTCCTGTAACACATATTATG $3^{\prime}$ & \\
\hline \multirow[t]{2}{*}{2} & Strong Culm & (SCM 2) (F) & 5'ATTCAGATCAATAGGTTGAGTGT3 & Ookawa et al., 2010 \\
\hline & & (SCM 2) (R) & 5'TGCTATGTATATCCTATCGGTTC 3' & \\
\hline \multirow[t]{2}{*}{3} & Heavy Panicle \& & OsSPL14(F) & 5'CAAGGGTTCCAAGCAGCGTAA3' & Ashikari et al., 2010 \\
\hline & Plant architecture & OsSPL14(R) & 5’TGCACCTCATCAAGTGAGAC3' & \\
\hline \multirow[t]{5}{*}{4} & $x a 5$ & xa5S (multiplex) & 5'GTCTGGAATTTGCTCGCGTTCGTGGTAAAGTAGATACCTTATCAA & Pradhan et al., 2015a \\
\hline & & & ACTGGAAGCTCGCCATTCAAGTTCTTTGAG3' & \\
\hline & & $x a 5 S R / R$ & 5'TGGTAAAGTAGATACCTTATCAAACTGGAAGCTCGCCATTCAAGT & \\
\hline & & (multiplex) & TCTTGAG & \\
\hline & & & TGACTTGGTTCTCCAAGGCTT3' & \\
\hline \multirow[t]{2}{*}{5} & Xa21 & pTA248F & 5'AGACGCGGAAGGGTGGTTCCCGGA3' & Pradhan et al., 2015a \\
\hline & & pTA248R & 5'AGACGCGGTAATCGAAGATGAAA3' & \\
\hline \multirow[t]{2}{*}{6} & SUB1A & Sub 1 A203 (F) & 5' CTT CTT GCT CAA CGA CAA CG 3' & Pradhan et al., 2015b \\
\hline & & Sub 1 A203 (R) & 5' AGG CTC CAG ATG TCC ATG TC 3' & \\
\hline \multirow[t]{2}{*}{7} & Sub1 BC2 & Sub 1 BC 2 (F) & 5' AAAACAATGGTTCCATACGAGAC 3' & Pradhan et al., 2015b \\
\hline & & Sub 1 BC $2(R)$ & 5' GCC TAT CAA TGC GTG CTC TT 3' & \\
\hline
\end{tabular}

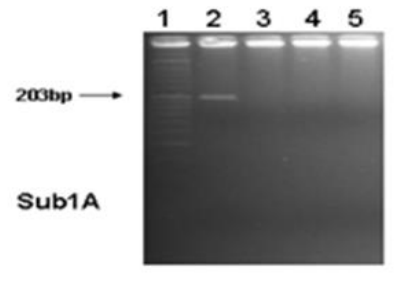

A

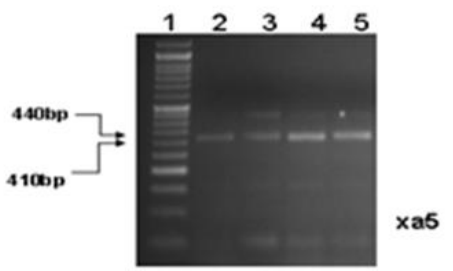

C

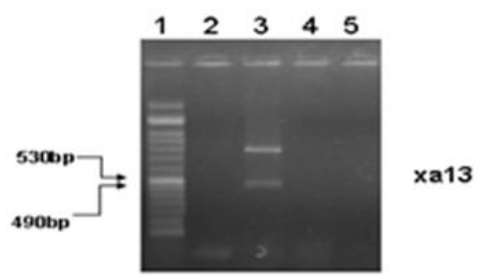

B

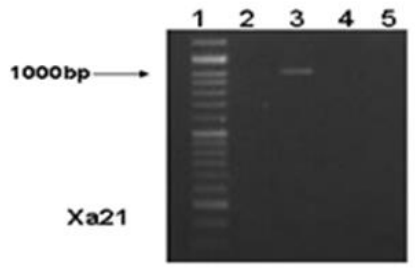

D

Fig 1. Gel photographs ofdonor parents (A) presence of expected base pair specific bands (203bp) for Sub1A tolerance QTL in SwarnaSub1 variety. Lane 1: represents DNA ladders; Lane 2: Swarna- Sub1; Lane 3 : Swarna MAS; (B) presence of specific band for BB resistance gene $x a 13$ (C) specific band for $x a 5$ and (D) band for Xa21.

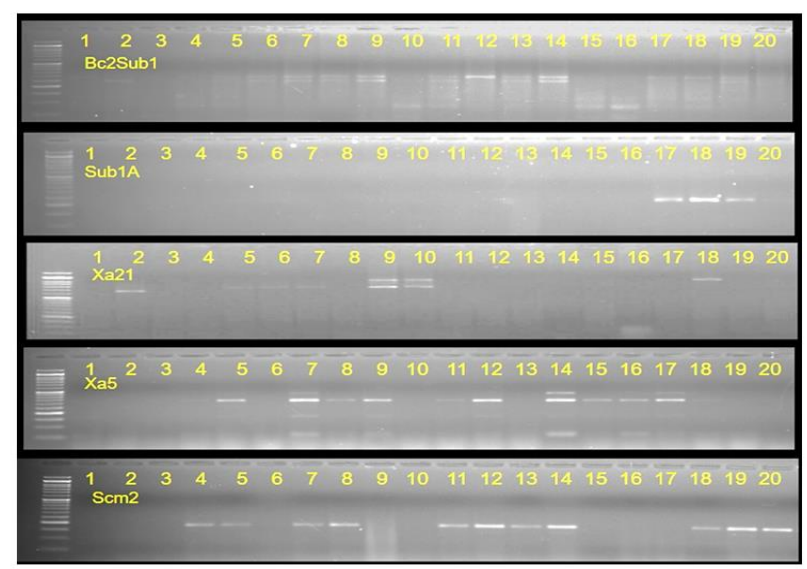

Fig 2. Representative electrophoregram of $B_{1} F_{1}$ derived lines of Swarna varieties using submergence tolerence $Q T L$ Sub1A, bacterial blight resistance genes $x a 5$ and Xa21and yield component QTLS GW2, OSSPL14 and SCM2.The numbers on the top of the lane indicate the genotype used as in theL:100 bp DNA ladder. Lanes 1-20: Represents backcross progenies from $B C_{1} F_{1}-S M 01$ to $B C_{1} F_{1}-S M 20$. 


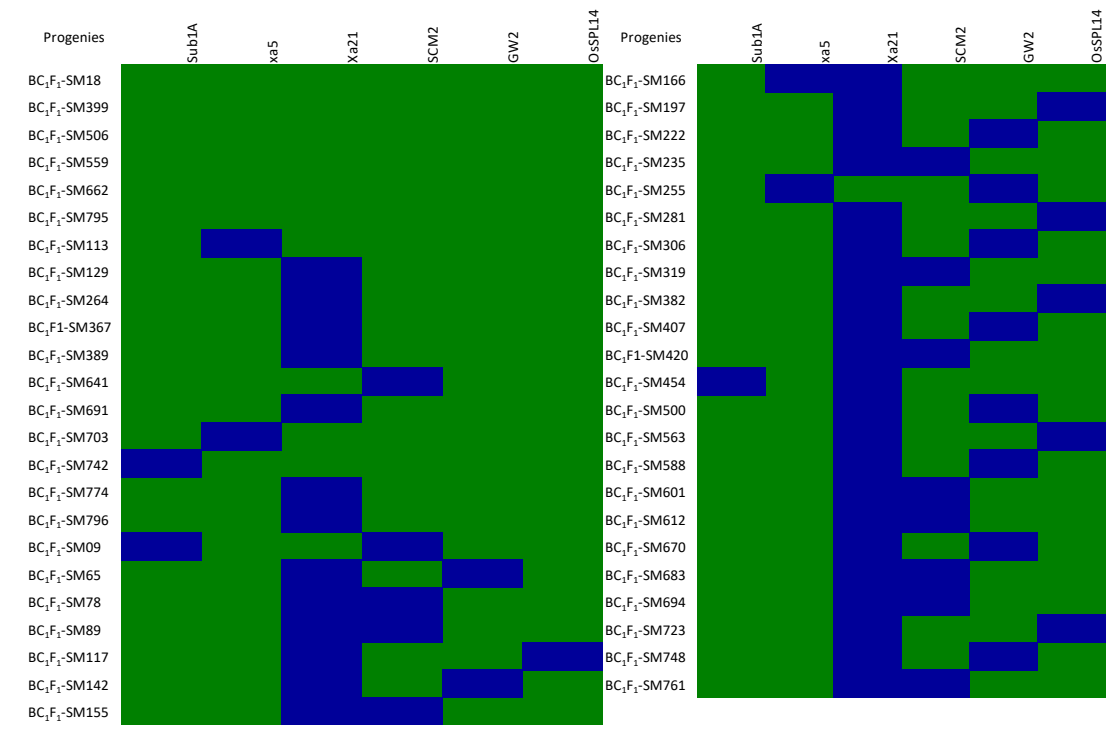

Fig 3. Banding analysis for submergence tolerance, bacterial blight resistance and yield component in $B C_{1} F_{1}$ derived lines for $G W 2$, OSSPL14, SCM2, SUb1A, xa5 and Xa21 genes/QTLs. Blue and green represents absence and presence of a particular gene in a progeny. This figure provides six, five and four genes/QTLs combinations in the genotyping progenies.

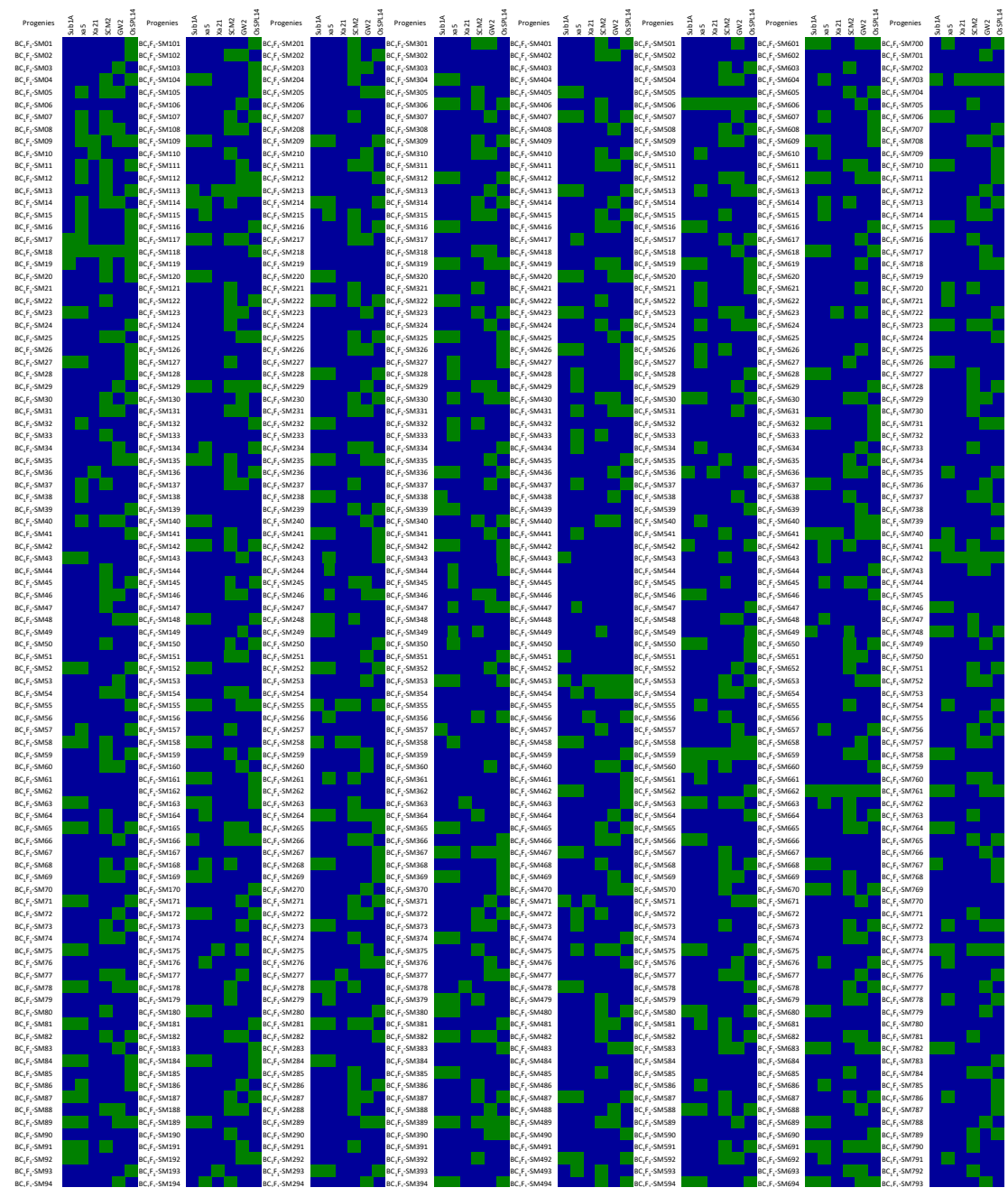

Fig 4. Banding analysis for submergence tolerance, bacterial blight resistance and yield components inBC $\mathrm{F}_{1}$ derived lines for $G W 2$, OsSPL14, SCM2,SUb1A, xa5 and Xa21 genes/QTLs. Blue and green represents absence and presence of a particular gene in a progeny. This figure provides six, five four three, two and one gene combinations genes/QTLs in the genotyping progenies. 
Swama-Sub1 x Swama MAS

$$
\downarrow
$$

F1

\author{
x Swama-Havataki derivative<smiles>C[C]1CCC1C</smiles> \\ F1' \\ X Swama
}

\title{
BC1F1
}

Fig 5. Schematic diagram for generation of backcross progenies for stacking of submergence tolerance, bacterial blight resistance and enhancing yield potential in rice variety, Swarna.

detected 241 plants positive for $x a 5$ gene and 125 plants positive for Xa21 resistance gene individually (Fig. 2; Fig.

3 ). The tightly linked molecular markers for some prominent traits have been identified and used for marker-assisted backcross breeding in rice including resistance to biotic stress bacterial blight resistance and abiotic stress submergence tolerance and additionally yield potential. Marker assisted gene pyramiding of key genes/QTLs has helped in tacking susceptibility for fore most diseases such as bacterial blight (Huang et al., 1997; Singh et al., 2001; Suh et al., 2011) and abiotic stress traits such as submergence tolerance (Neeraja et al., 2007; kharuddaula et al., 2011; Khanh et al., 2013; Divya et al., 2014) and yield potential.

In this present study, we observed many desirable genes individually but when it comes to combinations of genes with all 3 different characteristics, we found 6 plants out of total 796 which contains all the six genes/QTLs namelyGW2, OsSPL14, SCM2, Sub1A, xa5 and Xa21(Fig. 3). These are the most desirable progenies which will be used for further experiments. In the same experiment, we also found progenies with 5 gene combinations. Among these 5 gene combination progenies, seven plants $\left(B_{1} F_{1}-S M 129, B C_{1} F_{1}-S M 264, B C_{1} F_{1}\right.$ SM367, $\mathrm{BC}_{1} \mathrm{~F}_{1}-\mathrm{SM} 389, \mathrm{BC}_{1} \mathrm{~F}_{1}-\mathrm{SM} 691, \mathrm{BC}_{1} \mathrm{~F}_{1}-\mathrm{SM} 774$ and $\mathrm{BC}_{1} \mathrm{~F}_{1^{-}}$ SM796) showed the gene combination of GW2, OsSPL14, $\mathrm{SCM} 2$, Sub1A, $x a 5$ whereas two plants $\left(\mathrm{BC}_{1} \mathrm{~F}_{1}-\mathrm{SM} 113\right.$ and $\mathrm{BC}_{1} \mathrm{~F}_{1}$-SM703) had the same set of genes, but instead of $x a 5$ they possessed Xa21 (Fig 3; Fig 4). We also detected 30 progenies which showed 4 genes in different combinations. The genotyping results of progenies also exhibited 69 progenies having 3 gene combinations, 259 progenies having 2 gene combinations and 283 progenies having only a single gene (Fig. 3; Fig. 4). These progenies with desirable genes in different combinations can also be used further for different backcrossing programs. With the aid of gene introgression, this can lead to the development of submergence tolerant, bacterial blight resistant and high yield potential cultivar in Swarna background that may be more popular than the parent, Swarna.

\section{Materials and Methods}

Parental lines Swarna-Sub1, Swarna MAS were raised in 7 days staggered for hybridization. Crossing was performed using Swarna-Sub1 as female parent. Next season, the true $F_{1}$ plant was raised and crossed with Swarna- Havataki derivative to obtain $F_{1}{ }^{\prime}$ seeds. True hybridity was again checked using OsSPL14 gene specific marker and true $\mathrm{F}^{\prime}$ plant was hybridized with recipient parent Swarna to produce $B C_{1} F_{1}$ seeds.

Nursery of seven-ninety-six $B_{1} C_{1}$ generation plants of Swarna derived lines of Swarna derived plants for submergence

tolerance, bacterial blight resistance and yield QTLs for were planted. Here, QTL referred to Quantitative Trait Locus is a section of the DNA that is associated with a specific phenotypic trait and is correlated to polygenic effects. The progenies were grown in big trays in RGA-cum-Phytotron facility chamber under controlled condition. Thirty days old seedlings were transplanted in the main field and grown with the following standard agricultural practices. The schematic representation of the parent and pedigree of plants is shown below

\section{DNA Isolation}

Leaves of 30 days-old seedlings were collected from 796 progenies to extract genomic DNA for molecular screening of yield QTLs, submergence tolerance and bacterial leaf blight resistance in derived $\mathrm{BC}_{1} \mathrm{~F}_{1}$ lines. Genomic DNA was extracted after crushing the sample in liquid nitrogen in microfuge tubes using Cetyltrimethyl ammonium bromide (CTAB) extraction buffer $(100 \mathrm{mmol} / \mathrm{L}$ MTris- $\mathrm{HCl}$ in $\mathrm{pH}-8,20 \mathrm{mmol} / \mathrm{L}$ Ethylene- 
diamine-tetra-acetic acid (EDTA) $\mathrm{pH}-8,1.3 \mathrm{~mol} / \mathrm{L} \mathrm{NaCl}, 2 \%$ CTAB) and chloroform-isoamyl alcohol followed by the RNase treatment and ethanol precipitation (Murray and Thompson, 1980). Agarose gel electrophoresis was used to estimate DNA concentration and each sample was then diluted to approximately $30 \mathrm{ng} / \mu \mathrm{l}$.

\section{PCR amplification and visualization of markers}

PCR amplification of rice the varieties and progenies was done with gene-specific primers for the QTLs SCM2, OsSPL14, GW2 and Sub1A, and closely linked molecular markers for xa5 and Xa21 (Table 1). DNA amplification reaction was performed in a volume of $20 \mu \mathrm{l}$ containing1.5mMTris- $\mathrm{HCl}(\mathrm{pH} 8.75), 50 \mathrm{mM}$ $\mathrm{KCl}, 2 \mathrm{mM} \mathrm{MgCl} 2,0.1 \%$ Triton X-100, 200mM each of Deoxyadenosine-triphosphate (dATP), Deoxy-cytidine-triphosphate (dCTP), Deoxy-thymidine-triphosphate (dTTP), Deoxyguanosine-triphosphate (dGTP), 4 pmol of each forward and reverse primers (Table 1), 1 unit of Taq polymerase and 30ng of genomic DNA. Amplification was performed in a programmable Thermal Cycler (Veriti; Applied Biosystems, Life Technologies, Singapore). The reaction mixture was first denatured for $4 \mathrm{~min}$ at $94^{\circ} \mathrm{C}$ and then subjected to 35 cycles of 1 min denaturation at $94 \circ \mathrm{C}, 1 \mathrm{~min}$ annealing at 55-58으 (Table 1 ) and $1 \mathrm{~min}$ extension at $72 \circ \mathrm{C}$, and then a final extension for $10 \mathrm{~min}$ at $72 \circ \mathrm{C}$. Aliquots of $10 \mu \mathrm{I}$ of DNA products from PCR amplification were loaded in $2.5 \%$ agarose gel containing $0.8 \mu$ $\mathrm{g} / \mathrm{ml}$ ethidium bromide for electrophoresis in $1 \mathrm{X}$ Tris-BorateEDTA (TBE) (pH 8.0). A 50 bp DNA ladder was used for the determination of the size of amplicons. The gel was run at $120 \mathrm{~V}(2.5 \mathrm{~V} / \mathrm{cm})$ for 3 hours and photographed using a Gel-Doc System (SynGene). Molecular markers used for genotyping rice genotypes of the Sub1 gene, BB resistance genes and yield QTL cluster. The data were scored as $1 / 0$ (green/blue-Fig 3; Fig 4) for the presence/ absence of each target genes for primervariety combination.

\section{Conclusion}

Submergence tolerance with bacterial leaf blight resistance and yield potential improvement of popular rice variety Swarna may be possible using component trait genes and QTLS viz., Sub1A, xa5, Xa21, GW2, OsSPL14 and SCM2. The presence of these genes was detected in the backcross progenies in BC1F1 generation. The presence of bands for all six genes was seen in only six progenies. These plants will be used for further selection and evaluation studies.

\section{Acknowledgements}

The authors are highly grateful to the Director, ICAR-National Rice Research Institute, Cuttack for providing all the necessary facilities and to Vice-Chancellor North Orissa University for allowing this work for my Ph.D. work. SM acknowledges DST (Odisha), India for providing BijuPattnaik Fellowship.

\section{Reference}

Adhikari TB, Basnyat RC (1999) Virulence of Xanthomonas oryzae pv. Oryzae on rice lines containing single resistance genes and gene combinations. Plant Dis. 83:46-50.
Adhikari TB, Vera-Cruz CM, Zhang Q, Nelson RJ, Skinner DZ, Mew TW, Leach JE (1995) Genetic diversity of Xanthomonas oryzaepv. oryzae. Asia Appl Environ Microbiol. 61: 966-971.

Akagi H, Yokozeki Y, Inagaki IA, Fujimura T (1996) Microsatellite DNA markers for rice. Chen $M$, Presting $G$, Barbazuk WB, Goicoechea JL, Blackmon B and Fang G (2002) An integrated physical and genetic map of the rice genome. Plant Cell. 14: 537-545.

Ando T, Yamamoto T, Shimizu T, Ma XF, Shomura A, Takeuchi $Y$, Lin SY, Yano M (2008) Genetic dissection and pyramiding of quantitative traits for panicle architecture by using chromosomal segment substitution lines in rice. Theor Appl Genet. 116: 881-890.

Antonio BA, Sakata K, Sasaki T (2000) Rice at the forefront of plant genome informatics. Genome Inform. 11: 3-11.

Ashikari M1, Sakakibara H, Lin S, Yamamoto T, Takashi T, Nishimura A, Angeles ER, Qian Q, Kitano H, Matsuoka M (2005) Cytokinin oxidase regulates rice grain production. Science. 309:741-745.

Barry GF (2001) The use of the Monsanto draft rice genome sequence in research. Plant Physiol. 125:1164-1165.

Bharatkumar S, Paulraj RSD, Brindha PV, Kavitha S, Gnanamanickam SS (2008) Improvement of bacterial blight resistance in rice cultivars ajayothi and IR50 via markerassisted backcross breeding. J Crop Improve. 21:101-116.

Chen S, Jin W, Wang M, Zhang F, Zhou J, Jia Q (2003) Distribution and characterization of over 1000 TDNA tags in rice genome. Plant J. 36: 105-113.

Divya B, Robin S, Rabindran R, Senthil S, Raveendran M, Joel AJ (2014) Marker assisted backcross breeding approach to improve blast resistance in Indian rice (Oryza sativa) variety ADT43. Euphytica 200, 61-77. doi: 10.1007/s10681-0141146-9

Dingkuhn M, Penning de Vries FWT, De Datta SK, Van Laar HH (1991) Concepts for a new plant type for direct seeded flooded tropical rice. In: Direct-seeded flooded rice in the tropics. LosBaños (Philippines): International Rice Research Institute. 17-38.

Dixit N, Dokku P, Mithra SVA, Parida SK, Singh SK, Singh NK, Mohapatra T (2013) Haplotype structure in grain weight gene GW2 and its association with characteristics in rice. Euphytica. 192:55-61.

Donald CM (1968) The breeding of crop ideotypes. Euphytica. 17:385-403.

Evans LT (1993) Crop evolution, adaptation and yield. Cambridge (UK): Cambridge University Press.

Food and Agricultural Organization (2009) FAO STAT database FAO, Rome, www.faostat.org.

Gao X, Zhu XD, Fang N, Duan PG, Luo YH Li YH (2015) Identification of QTLs for grain size and characterization of the beneficial alleles of grain size genes in large grain rice variety BL129. J Integ Agri. 610:43-7.

Gu K, Sangha JS, Li Y, Yin Z (2008) High resolution genetic mapping of bacterial blight resistance gene Xa10. Theor Appl Genet. 116:155-163

Hampl V, Pavlicek A, Flegr J (2001) Construction and bootstrap analysis of DNA fingerprinting based phylogenetic trees with the freeware program FreeTree: application to trichomonad parasites. Intl J Syst Evol Microbiology. 51:731-735.

Huang N, Angeles ER, Domingo J, Magpantay G, Singh S, Zhang, G, Kumaravadivel N, Bennett J, Khush GS (1997) Pyramiding 
bacterial blight resistance gene in rice: markerassistited selection using RFLP and PCR. Theor Appl Genet. 95:313-320.

Iftekharuddaula KM, Newaz MA, Salam MA, Ahmed HU, Mahbub MAA, Septiningsih EM, Collard BCY, Sanchez DL, Pamplona AM, Mackill DJ (2011) Rapid and high-precision marker assisted backcrossing to introgress the SUB1 QTL into BR11, the rainfed lowland rice mega variety of Bangladesh. Euphytica 178, 83-97.

Iyer AS, McCouch SR (2004) The Rice Bacterial Blight Resistance Gene xa5 Encodes a Novel Form of Disease Resistance. The American Phytopathological Society. 17:1348 $-1354$

Jennings PR (1964) Plant type as a rice breeding objective. Crop Sci. 4:13-15.

Khanh TD, Linh LH, Linh TH, Ham LH, Xuan TD (2013) Rapid and high-precision marker assisted backcrossing to introgress the SUB1 QTL into the Vietnamese elite rice variety. J. Plant Bred Crop Sci. 5: 26-33.

Khush GS (1995) Breaking the yield frontier of rice. Geo Journal. 35: 329-332.

Khush GS and Peng S (1996) Breaking the yield frontier of rice. In: Increasing yield potential in wheat: breaking the barriers. Reynolds MP, Rajaram S, McNabA, editors. El Batán (Mexico): International Maize and Wheat Improvement Center. 36-51.

Khush GS, Virk PS, EvangelistaA, Romena B, Pamplona A, LopenaV, DelaCruzN, Peng S, Cruz CV, Cohen M (2001) Germplasm with high yield potential. In: 2001 annual Report, Los Baños (Philippines): International Rice Research Institute. 4-5.

McCouch SR, Teytelman I, Xu Y, Lobos KB, Clare K, Walton M, FuB, Maghirang R, Li Z, Xing $Y$, Zhang $Q$, Kono I, Yano $M$, Fjellstrom R, Declereck G, Schneider D, Cartinhour S, Ware D, Stein L (2002) Development and mapping of 2240 new SSR markers for rice (Oryza sativa L.). DNA Res. 9: 199-207.

Mohanty SP, Kumbhakar S, Pandit E, Barik SR, Mohanty DP, Nayak DK, Singh NR and Pradhan SK (2016) Molecular screening of yield component QTLs for strong culm, grain number and grain width using gene specific markers in indica- tropical japonica derived rice lines. Oryza. 53(2): 136143.

Murray MG, Thompson WF (1980) Rapid isolation of highmolecular weight plant DNA. Nucl. Acids Res. 8: 43214326.

Neeraja $C$, Maghirang-Rodriguez R, Pamplona A, Heuer $S$, Collard B, Septiningsih EM, Vergara G, Sanchez D, Xu K, Ismail AM, Mackill DJ (2007) A marker-assisted backcross approach for developing submergence-tolerance rice cultivars. Theor Appl Genet. 115:767-776.

Central Rice Research Institute (2013) Vision 2050. pp.9

Paterson AH, Bowers JE, Van de Peer Y, Vandepoele K (2005) Ancient duplication of cereal genomes. New Phytologist. 165(3):658-61.

Pradhan SK, Nayak DK, Pandit, Pandit E, Anandan A, Mukherjee AK, Lenka SK, Behera L and Barik D (2016) Incorporation of bacterial blight resistance genes into lowland rice cultivar through marker-assisted backcross breeding. Phytopathology. 106: 10.1094/PHYTO-09-15-0226-R.
Pradhan SK, Nayak DK, Mohanty S, Behera L, Barik SR, Pandit E, Lenka S (2015) Pyramiding of three bacterial blight resistance genes for broad-spectrum resistance in deepwater rice variety, Jalmagna. Rice. 8(19): DOI 10.1186/s12284-0150051-8.

Pradhan SK, Barik SR, Sahoo J, Pandit E, Nayak DK, Pani D, Anandana A (2015b) Comparison of Sub1 markers and its combinations for submergence tolerance and analysis of adaptation strategies of rice in rainfed lowland ecology. Comptes Rendus Biology. 338(10):650-9.

Pradhan SK, Chakraborti M, Chakraborty K, Behera L, Meher J, Subudhi HN, Mishra SK, Pandit E and Reddy JN (2018) Genetic Improvement of Rainfed Shallow-lowland Rice for Higher Yield and Climate Resilience, In Book Rice Research for enhancing productivity, profitability and climate resilience. pp.107-121.

Rao KK, Lakshminarasu M, Jena KK (2002) DNA markers and marker-assisted breeding for durable resistance to bacterial blight of rice. Biotechnol Adv. 20:33-47.

Singh S, Sidhu JS, Huang N, Vikal Y, Li Z, Brar DS, Dhaliwal HS, Khush GS (2001) Pyramiding three bacterial blight resistance genes (xa5, xa13 and Xa21) using marker-assisted selection into indica rice cultivar PR-106. Theor Appl Genet. 102:10111015.

Song XJ, Huang W, Shi M, Zhu MZ, Lin HX, Wang YX, Frei M, Song QL, Yang LX (2011) The impact of atmospheric CO2 concentration enrichment on rice quality -A research review. Acta Eco Sinica. 31: 277-282.

Sonti RV (1998) Bacterial leaf blight of rice: new insights from molecular genetics. Curr Sci. 74:206-212.

Suh JP, Jeung JU, Noh TH, Cho YC, Park SH, Park HS, Shin MS, Kim CK, Jena KK (2013) Development of breeding lines with three pyramided resistance genes that confer broadspectrum bacterial blight resistance and their molecular analysis in rice. Rice. 6:5.

Yoshimura S, Yoshimura A, Iwata N, McCouch SR, Abenes SL, Baraoidan MR, Mew TW, Nelson RJ (1995) Tagging and combining bacterial blight resistance genes in rice using RAPD and RFLP markers. Mol Breed. 1(4):375-387.

Zhang YD, Zhang YH, Dong SL, Chen T, Zhao QY, Zhu Z, Zhou LH, Yao S, Zhao L, Yu X, Wang CL (2013) QTL Mapping for grain size traits based on extra-large grain rice line TD70. Rice Science. 20(6):400-406. 